\title{
ADAPTIVE ROLE OF INTERCHANGE HETEROZYGOSITY IN THE ANNUAL CHRYSANTHEMUM
}

\author{
R. S. RANA and H. K. JAIN \\ Botany Division, Indian Agricultural Research Institute, New Delhi
}

Received ro.viii. 64

\section{INTRODUCTION}

Although the chromosome theory of heredity was established within a decade or so of the rediscovery of the Mendelian laws of heredity, the full significance of organisation of genetic material in this form could not be appreciated for a long time. The discoveries of position effect, of predominance of certain chromosomal rearrangements in the population of several species and more recently of the adaptively organised blocks of related genes in Salmonella (Demerec, 1956) have made it clear that the chromosomal organisation has important functional and evolutionary implications. Observations on the incidence and establishment of structural heterozygosity in natural populations have been particularly instructive in this regard as shown by the classical studies of Darlington and his collaborators (1938, 1956). The present report relates to chromosomal interchanges in different populations of annual chrysanthemum, their predominance over the homozygotes and their mechanical characteristics.

\section{MATERIAL AND METHOD}

Chrysanthemum carinatum is a common garden annual distinguished from other species of this group by its carinated involucral bracts and solitary flower-heads, often with a yellow coloured ring at the base of the petals. The species has 18 as its diploid chromosome number, and like several other members of the family Compositz is self-incompatible (Jain and Gupta, 1960). Seven different populations-five local and two from abroad have been analysed. The local material came from different parts of Delhi, sufficiently isolated from one another to preclude interbreeding. The two imported varieties were obtained from Hungary and from the Chelsea Physic Garden, London. Flower buds from a large number of plants of each of the seven groups were fixed in Carnoy's solution mordanted with ferric chloride. The anthers were squashed in acetocarmine and the chromosomal associations examined in pollen mother cells at diakinesis and metaphase.

\section{OBSERVATIONS}

(i) Local populations

Observations on pollen mother cells in a large number of plants revealed the presence of two types of individuals: those regularly forming nine bivalents (plate I) and others showing a multiple of four chromosomes (plate I) in a large number of their cells. A possible explanation for the occurrence of multiple association of chromosomes in these plants could be that the basic chromosome number for the 
genus is lower than 9 so that individuals with 18 chromosomes can be considered as primary or secondary polyploids. A number of considerations, however, argued against this interpretation. In the first place, available information on chromosome count in Chrysanthemum does not provide evidence in support of a lower basic number (Darlington and Wylie, 1955). Secondly, the clear division of plants into two groups, with and without multiple associations, is inconsistent with a possible polyploid nature. Thirdly, observations on the karyotype made on mitotic preparations give no indication that more than two chromo-

TABLE I

Incidence of interchange heterozygosity in local populations

\begin{tabular}{|c|c|c|c|c|}
\hline \multirow{3}{*}{ Sample No. } & \multirow{3}{*}{$\begin{array}{l}\text { No. of plants } \\
\text { analysed }\end{array}$} & \multicolumn{3}{|c|}{ Classes } \\
\hline & & \multirow{2}{*}{$\begin{array}{c}\text { Homozygotes } \\
\text { (9 II) }\end{array}$} & \multicolumn{2}{|c|}{ Heterozygotes } \\
\hline & & & $(\mathrm{I} I \mathrm{~V}+7 \mathrm{II})$ & $(2 \mathrm{IV}+5 \mathrm{II})$ \\
\hline $\begin{array}{l}\text { A } \\
\text { B } \\
\text { C } \\
\text { D } \\
\text { E }\end{array}$ & $\begin{array}{l}15 \\
15 \\
15 \\
15 \\
15\end{array}$ & $\begin{array}{l}4 \\
5 \\
2 \\
4 \\
2\end{array}$ & $\begin{array}{r}11 \\
9 \\
13 \\
11 \\
10\end{array}$ & $\begin{array}{l}0 \\
1 \\
0 \\
0 \\
3\end{array}$ \\
\hline Total . & 75 & 17 & 54 & 4 \\
\hline
\end{tabular}

somes may be homologous to one another. These considerations and the breeding behaviour of the plants showing multiples clearly indicated that they were interchange heterozygotes.

Observations on the frequency of structural heterozygotes in the five local populations are presented in table I. It will be seen that these plants predominate in all, the five samples, their number ranging from 66.7 to 86.7 per cent. It is also clear that an interchange involving two of the chromosome pairs is more commonly present; plants having two independent multiples (plate I, 3 and 4 ) being rare. The single interchange multiple was found to be formed in most of the pollen mother cells observed and the closed ring configuration with 4 chiasmata was far more frequent than the chain type having 3 chiasmata (see table 3).

\section{(ii) Hungarian and English varieties}

The varieties Spectalite from Hungary and Chelsea from England, like the local populations described above, showed interchange multiples in many of their plants. Observations on the frequency of heterozygotes in these two varieties are presented in table 2. It will be seen that while the English variety, like most plants of the local material, shows only one interchange, the Hungarian type differs in having a 
large number of plants in which two interchanges are present, although these are not as numerous as those with a single rearrangement. In these two varieties, as in the locals, the penetrance of multiple formation

TABLE 2

Incidence of interchange heterozygosity in the imported varieties

\begin{tabular}{|c|c|c|c|c|}
\hline \multirow{3}{*}{ Variety } & \multirow{3}{*}{$\begin{array}{l}\text { No. of plants } \\
\text { analysed }\end{array}$} & \multicolumn{3}{|c|}{ Classes } \\
\hline & & \multirow{2}{*}{$\begin{array}{l}\text { Homozygotes } \\
\text { (9 II) }\end{array}$} & \multicolumn{2}{|c|}{ Heterozygotes } \\
\hline & & & $(\mathrm{I} I \mathrm{~V}+7 \mathrm{II})$ & $(2 \mathrm{IV}+5 \mathrm{II})$ \\
\hline $\begin{array}{l}\text { Spectalite } \\
\text { (Hungary) }\end{array}$ & $4^{2}$ & 8 & 21 & 13 \\
\hline $\begin{array}{l}\text { Chelsea } \\
\text { (England) }\end{array}$ & 200 & $14 I$ & 59 & o \\
\hline Total . & 242 & I 49 & 80 & 13 \\
\hline
\end{tabular}

in the pollen mother cells was nearly complete and rings outnumbered the chains by a wide margin (table 3 ).

(iii) Interpopulation analysis

Plants of one of the local populations showing a single interchange were crossed with similar plants of the Hungarian and the Chelsea groups. Observations on the progeny derived from these crosses failed

TABLE 3

Degree and type of multiple formation

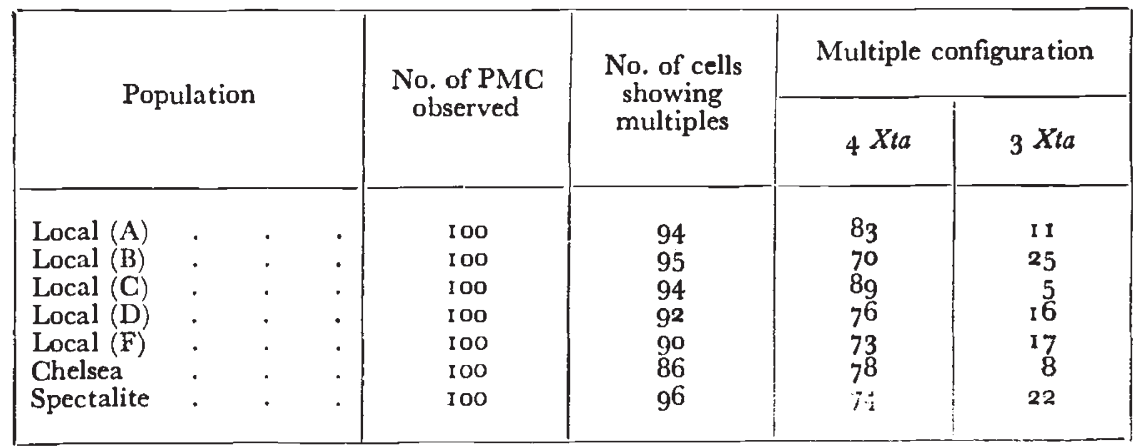

to give any individual combining in it two interchanges. Only two types of plants, structurally homozygous or heterozygous, like the parental types, could be recovered from these crosses as shown in table 4. It could be concluded that two common pairs of chromosomes were involved in the structural rearrangement in the three populations.

A cross was also made involving the Hungarian and one of the 
local varieties, selecting this time parents which were heterozygous for two separate interchanges. The chromosome analysis on the derivatives of this cross indicated that the parental plants differ from one another with regard to one of the two interchanges, the other involving common chromosome pairs (see table 4).

\section{(iv) Fertility and multiple orientation}

The interchange heterozygotes were found to show an unusually high degree of pollen and seed fertility which was only slightly lower than that of the corresponding homozygotes. Since fertility in such plants depends on the manner of orientation of the interchange multiple, observations were made on the metaphase arrangement of

TABLE 4

Interpopulation analysis of chromosomal interchanges

\begin{tabular}{|c|c|c|c|c|c|c|}
\hline \multirow{2}{*}{$\begin{array}{c}\text { Cross } \\
\text { no. }\end{array}$} & \multirow{2}{*}{ Parents } & \multirow{2}{*}{$\begin{array}{l}\text { Cytological } \\
\text { characteristics } \\
\text { of the parents }\end{array}$} & \multicolumn{4}{|c|}{ Types and frequencies of progeny plants } \\
\hline & & & $9 \mathrm{II}$ & $7 \mathrm{II}+1 \mathrm{IV}$ & $5 \mathrm{II}+2 \mathrm{IV}$ & $3 \mathrm{II}+3 \mathrm{IV}$ \\
\hline 1 & $\begin{array}{l}\text { Chelsea } \times \\
\text { Local (E) }\end{array}$ & $\begin{array}{l}7 \mathrm{II}+\mathrm{IIV} \\
7 \mathrm{II}+\mathrm{IV}\end{array}$ & 7 & 13 & - & - \\
\hline 2 & $\begin{array}{l}\text { Spectalite } \times \\
\text { Local (E) }\end{array}$ & $\begin{array}{l}7 \mathrm{II}+1 \mathrm{IV} \\
7 \mathrm{II}+\mathrm{I} \mathrm{IV}\end{array}$ & 5 & 15 & - & - \\
\hline 3 & $\begin{array}{l}\text { Spectalite } \times \\
\text { Chelsea }\end{array}$ & $\begin{array}{l}7 \mathrm{II}+1 \mathrm{IV} \\
7 \mathrm{II}+1 \mathrm{IV}\end{array}$ & 9 & I I & - & - \\
\hline 4 & $\begin{array}{l}\text { Spectalite } \times \\
\text { Local }(E)\end{array}$ & $\begin{array}{l}5 \mathrm{II}+2 \mathrm{IV} \\
5 \mathrm{II}+2 \mathrm{IV}\end{array}$ & 2 & II & 6 & $\mathbf{I}$ \\
\hline
\end{tabular}

chromosomes in the pollen mother cells. For a study of the possible relationship between the frequency of disjunctional orientation of the multiple and the degree of fertility, a sample of ten plants was taken and 40 pollen mother cells scored in each of these. Observations on the frequency of disjunctional orientation (alternate chromosomes going to the same pole) in these plants and the corresponding pollen and seed fertility values are presented in table 5. A statistical analysis of these observations is summarised in table 6 .

The analysis shows that the values of correlation coefficient are significant with a high degree of probability indicating a strong positive correlation between the frequency of disjunctional orientation and fertility, as measured by pollen stainability and seed setting. A more useful approach to the study of simultaneous variation of the three charactere may be the consideration of regression as shown in text-fig. $I$. It will be seen that the observed values of pollen and seed fertility lie more or less on the respective straight lines of linear regression, which rise with increasing values of disjunctional orientation. With this relationship established, it is clear that the unusually high degree of fertility in the interchange heterozygotes is due to a pronounced tendency of the interchange multiple to show preferentially a particular type of oricntation at metaphase. 


\section{DISCUSSION}

The preponderance of interchange hetcrozygotes in the different populations clearly underlines the adaptive value of these chromosomal rearrangements in the evolution of the diploid varietics of Chrysanthemum carinatum. It is not suggested that the plants from the three different

TABLE 5

Observations on disjunctional orientation and fertility

\begin{tabular}{|c|c|c|c|c|c|}
\hline \multirow{2}{*}{$\begin{array}{l}\text { Plant } \\
\text { no. }\end{array}$} & \multirow{2}{*}{$\begin{array}{c}\text { No. of PMC } \\
\text { analysed }\end{array}$} & \multicolumn{2}{|c|}{ Type of orientation } & \multirow{2}{*}{$\begin{array}{c}\text { Pollen } \\
\text { fertility } \\
\text { (per cent.) }\end{array}$} & \multirow{2}{*}{$\begin{array}{c}\text { Seed } \\
\text { fertility } \\
\text { (per cent.) }\end{array}$} \\
\hline & & Disjunctional & Non-disjunctional & & \\
\hline I & 40 & 35 & 5 & $91 \cdot 7$ & $71 \cdot 4$ \\
\hline 2 & 40 & 35 & 5 & 89.2 & $75 \cdot 3$ \\
\hline 3 & 40 & 37 & 3 & 94.8 & 79.9 \\
\hline 4 & 40 & 35 & 5 & 87.8 & 73.8 \\
\hline 5 & 40 & 36 & 4 & $94 \cdot 5$ & $79 \cdot 1$ \\
\hline 6 & 40 & 35 & 5 & $93^{\circ} \mathrm{I}$ & $76 \cdot 5$ \\
\hline 7 & 40 & 34 & 6 & 89.4 & 69.4 \\
\hline 8 & 40 & 37 & 3 & $95 \cdot 6$ & 81.7 \\
\hline 9 & 40 & 35 & 5 & $90 \cdot 3$ & $79 \cdot 6$ \\
\hline 10 & 40 & 37 & 3 & $9^{2 \cdot 9}$ & $79^{\cdot 2}$ \\
\hline
\end{tabular}

regions represent distinct geographical races. It seems more likely that they are all parts of one cosmopolitan garden population. The selection in favour of structural heterozygosity including that resulting from interchanges has been reported earlier in several plant and animal species (Darlington, 1956; Dobzhansky, r 957; Burnham, 1956; Rees, I96r; Lewis and John, 1958). The present analysis brings out this selective value in a particularly striking way by two types of

TABLE 6

Correlation coefficients between frequency of disjunctional orientation of the interchange multiple and (i) pollen fertility (ii) seed fertility

\begin{tabular}{|l|c|c|}
\hline \multicolumn{1}{|c|}{ Factors } & $\begin{array}{c}\text { Correlation } \\
\text { coefficient } \\
(r)\end{array}$ & $\begin{array}{c}\text { Value of } r \\
\text { required for } \\
\text { significance at } \\
\mathbf{P}=0 \cdot 0 \text { I for 8 d.f. }\end{array}$ \\
\hline I. Disjunctional orientation and pollen fertility & $+0 \cdot 7784$ & $0 \cdot 765$ \\
2. Disjunctional orientation and seed fertility & $+0 \cdot 7873$ & $0 \cdot 765$ \\
\hline
\end{tabular}

observations. First, the establishment of interchange heterozygosity has occurred, possibly independently, in very widely separated populations. Secondly, and this is more important, the same two pairs of chromosomes are found to be involved in rearrangement in three of the different varieties tested for this purpose. The observations presented in table 4 indicate that there is a basic segmental type as has been reported for Campanula (Darlington and Gairdner, 1938). The 
second interchange is limited almost entirely to the Hungarian stock. It is clear that it is rearrangement affecting a particular set of genes, rather than structural heterozygosity per se, which has conferrred an

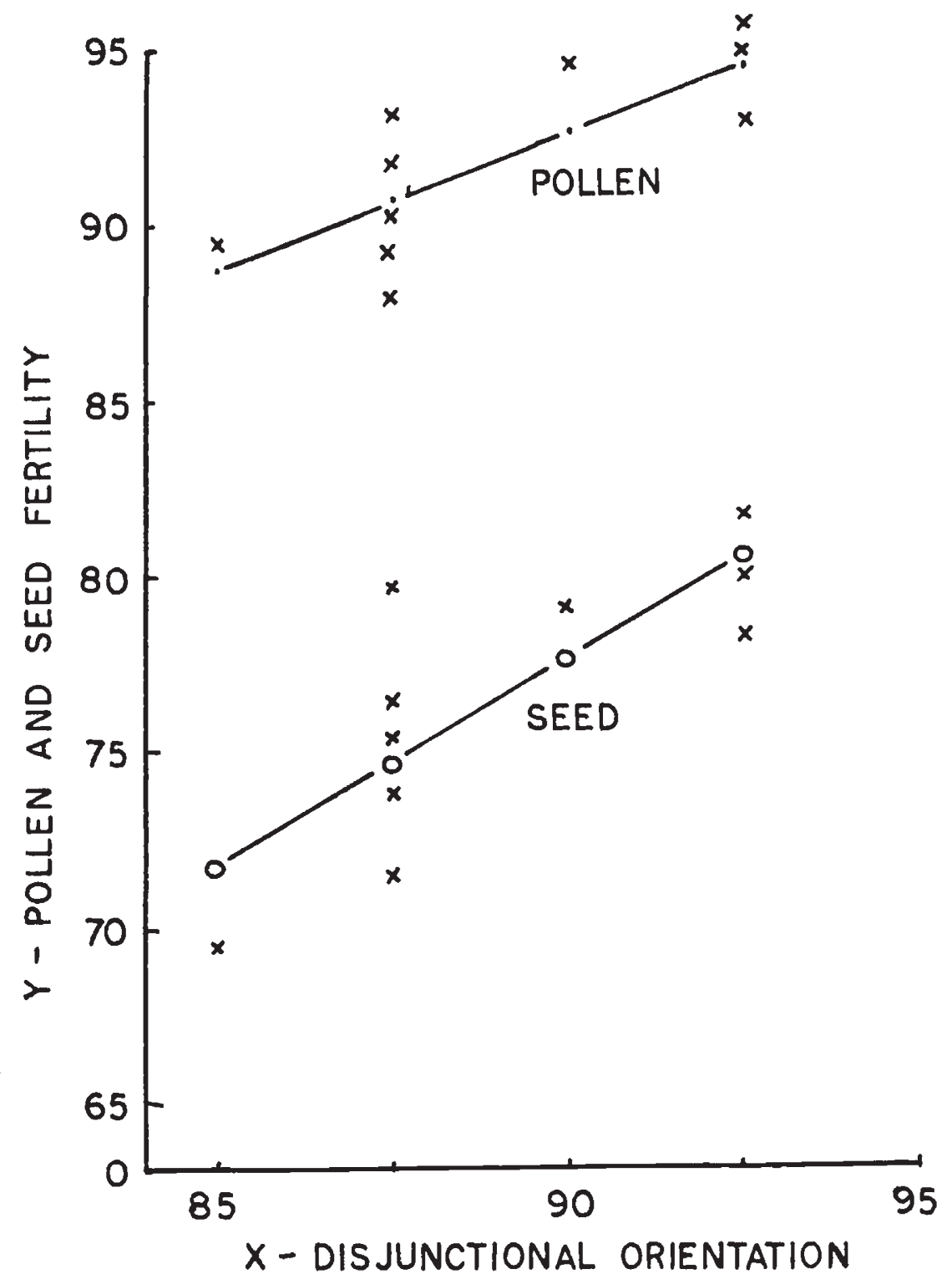

TEXT-FrG. I.-Diagram showing regressions of pollen and seed fertility $(\mathrm{Y})$ on disjunctional orientation of the interchange multiple $(\mathrm{X})$.

advantage. The observations of Thompson and Rees (1956) on different interchange heterozygotes in rye similarly show that selection operates not in favour of heterozygotes in general but of a particular heterozygous combination. 
The advantage associated with chromosomal rearrangements in a population may be potential or immediate. The potential value of interchange heterozygosity for the population was indicated in a remarkable way by the observations of Darlington and La Cour ( I 950) on Campanula and by those of Lewis and John (1958) on Periplaneta americana. These authors found that the structurally heterozygous individuals tended to replace the homozygous ones under imposed conditions of inbreeding. The observations on Campanula showed why this should be so. Darlington and La Cour found that the elimination of homozygotes was never so complete in the progeny obtained from the intercrossing of different heterozygotes, as in their respective selfed progenies. These results made it clear that selection operated in favour of genic heterozygosity and in an inbreeding population structural rearrangements provide the only means of preserving it. Darlington ( 1963 ) has interpreted these observations in terms of the concept of hybridity optimum which inplies that each species has an optimum degree of heterozygosity to which it is accustomed, any departure from which results in deleterious effects.

In the annual chrysanthemum, the possibility that the establishment of structural heterozygosity owes itself to similar conditions of inbreeding cannot be ruled out. All the varieties included in the present study have been developed for their ornamental quality and the continued selection for uniformity must necessarily mean an increasing degree of restriction on the possible number of recombinants, even though the breeding system of the plant is based on complete outcrossing. An alternative explanation would be that the observed rearrangement in the annual chrysanthemum may have been of immediate value. This is indicated by the observation, emphasised earlier, that selection in the different varieties has taken place in favour of translocation in the same pairs of chromosomes, rather than for structural heterozygosity in general. Moreover. the fact that structural heterozygotes are favoured even in the crossed families, as shown by the observations presented in table 4 , would sugge. . nat sulection in this case is relatively independent of the genetic background of the individual plants. An attempt will be made, however, to find whether the heterozygotes are favoured more in progenies from the intravarietal crosses compared to those from the inter-varietal.

It seems probable that the rearrangement affecting these chromosome pairs has helped to establish a linked combination of genes which is particularly favourable from the point of view of fitness. Such a group of genes would correspond to what Darlington and Mather (1952) have called a "super gene" and would be inherited as a unit because of the suppression of crossing over in it. The condition of structural heterozygosity provides ideal condition for such a suppression not only in the interstitial segments but also in other parts where chiasmata may not be formed due to a localised distribution. A good example of what appears to be a similar block of linked genes 
of adaptive value which, however, does not apparently depend on structural heterozygosity for its maintenance, is provided by the observations of Müntzing ( 1963 ) in an inbred stock of rye.

The rearrangement in the annual chrysanthemum is also of interest for the observed disjunctional orientation of the interchange multiple in most of the pollen mother cells. Some of the factors which would favour such an orientation in the present material are quite obvious. A karyomorphological analysis on the structural heterozygotes shows the symmetry of the rearrangement which leaves the median position of the centromere undisturbed in the reconstituted chromosomes. This factor and the fact that no chiasma was ever found to be formed in any of the two interstitial segments, would favour disjunctional separation as suggested by the earlier observations of Darlington (1958) and those of Sax and Anderson (1933). The marked non-randomness in the orientation of the multiple, however, can hardly be explained fully on considerations of this nature and it must be supposed that the disjunctional arrangement has evolved as a result of selection for this condition. Evidence pointing to a genotypic control of disjunctional orientation of the interchanged chromosomes in rye has been described by Thompson (1956). Consistent with this finding, Lawrence (1958) has shown that selection can be effectively practised in a segregating population of interchange heterozygotes to increase the frequency of disjunction. The finding of Lawrence ( 1963 ) that newly induced interchanges may also show a directed segregation of their chromosomes, which cannot be explained on mechanical considerations alone, is of considerable interest from the point of view of the nature of genotypic control. This author has suggested that the influence on orientation may be a secondary effect of factors whose primary effect is of selective importance in normal, non-interchange individuals; or alternatively, direct selection for a high disjunction frequency may have occurred in a manner analogous to Fisher's theory of the evolution of dominance.

\section{SUMMARY}

Interchange heterozygosity has been found to be adaptively established in different varieties of annual chrysanthemum, geographically isolated from one another over vast regions. It was obscrved that chromosomal rearrangements affecting two common pairs of chromosomes have been particularly selected in the evolution of these varieties. The high degree of fertility of the heterozygotes was found to be correlated with the disjunctional orientation of the interchange multiple in most of the pollen mother cells. The possible nature of the advantage conferred by the heterozygous condition is discussed.

Acknowledgments.-We thank Drs B. P. Pal, M. S. Swaminathan and S. K. Jain for their interest in this study. We are particularly grateful to Professor C. D. Darlington, F.R.s., for critically examining the manuscript and offering several valuable suggestions. 

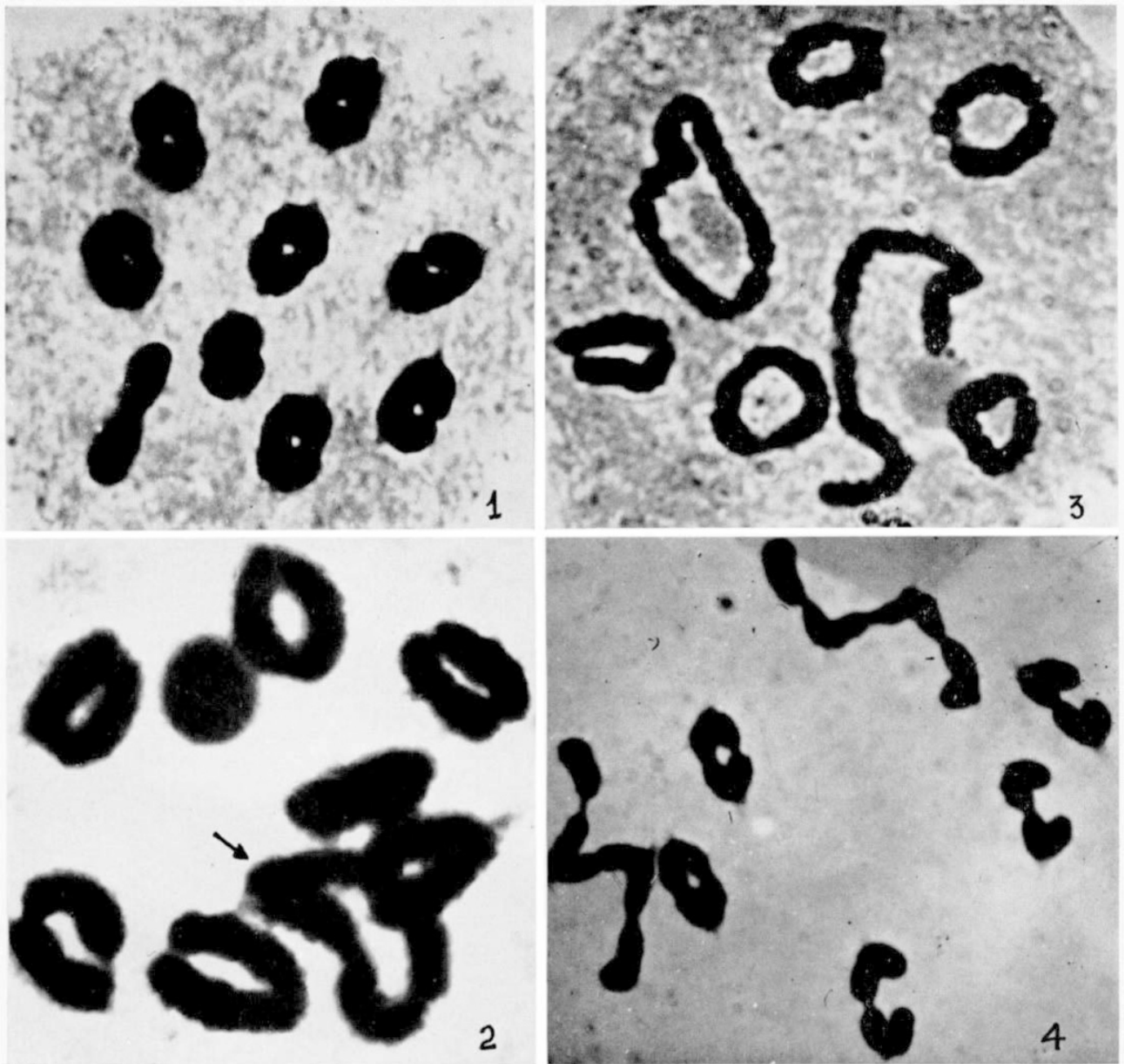

FIG. I - - PMC from a structurally homozygous plant showing the 9 bivalents. $\times 235^{\circ}$.

FIG. 2.-The single interchange multiple of four chromosomes (arrow) along with 7 bivalents is seen in this cell at the diakinesis stage. $\times 235^{\circ}$.

FIG. 3.-Two separate multiples of four chromosomes in a cell from variety Spectalite. $\times 235^{\circ}$.

FIG. 4.-The two interchange multiples in this coll are showing a distinct tenclency for disjunctional orientation. $\times 2$ I 75 . 


\section{REFERENCES}

BURnham, C. R. 1956. Chromosomal interchanges in plants. Bot. Rev., 22, 419-552. Darlington, C. D. 1937. Recent Advances in Cytology. and Ed. London: Churchill. DARLINGTON, C. D. 1956. Natural populations and the breakdown of classical genetics. Proc. Roy. Soc. B, 145, 350-364.

DARLING'Ton, C. D. 1958. The Evolution of Genetic Systems. Cambridge: Cambridge University Press.

darlington, C. D. 1963 . Chromosome Botany and the Origins of Cultivated Plants. Revised 2nd Ed. London: Allen \& Unwin.

DARLINGTON, C. D., AND GAIRDNER, A. E. 1938. The variation system in Campanula persicifolia. 7. Genet., 35, 97-128.

DARLINGTON, C. D., AND LA COUR, L. F. 1950. Hybridity selection in Campanula. Heredity, 4, 21 7-248.

Darlington, C. D., AND Mather, K. 1952. The Elements of Genetics. London: Allen \& Unwin.

Darlington, C. D., AND WYlie, A. P. 1955. Chromosome Atlas of Flowering Plants. London: Allen \& Unwin.

DEMEREC, м. 1956. A comparative study of certain gene loci in Salmonella. Cold Spring.Harbor Symp. Quant. Biol., 21, I I3-1 21.

ровzhansky, т. 1957. Mendelian populations as genetic systems. Cold Spring Harbor Symp. Quant. Biol., 22, 385-393.

JAIN, H. K., AND GUPTA, s. B. I 960 . Genetic nature of self-incompatibility in annual chrysanthemum. Experientia, $16,3^{6} 4$.

LAWRENCE, c. W. 1958. Genotypic control of chromosome behaviour in rye. VI. Selection for disjunction frequency. Heredity, I2, 127-1 31 .

LAWRENCE, c. W. I963. The orientation of multiple associations resulting from interchange heterozygosity. Genetics, 48, 347-350.

LeWIs, K. R., AND John, B. 1958 . Studies on Periplaneta americana. III. Selection for heterozygosity. Heredity, I2, 185-197.

MUNTZING, A. 1963. A case of preserved heterozygosity in rye in spite of longcontinued inbreeding. Hereditas, 50, 377-413.

REES, H. I961. The consequences of interchanges. Evolution, I5, I45-152.

SAX, K., AND ANDERSON, E. 1933. Segmental interchange in chromosomes of Tradescantia. Genetics, $18,53-67$.

тномpson, J. в. 1956. Genotypic control of chromosome behaviour in rye. II. Disjunction at meiosis in interchange heterozygotes. Heredity, Io, 99-108.

THOMPSON, J. B., AND REES, н. 1956. Selection for heterozygotes during inbreeding. Nature, $177,385-3^{86}$. 